\title{
The Assembly of a Criminal Self
}

\author{
Seán Manning and David A. Nicholls
}

\author{
Psychotherapist, Dunedin; Auckland University of TeChNology
}

\section{Whakarāpopotonga}

Ka tīmatahia ki te wheako mahitanga i te taha o ngā tāne i roto i te whareherehere me ètahi atu he rahi tonu nei te wheako herehere, te katoa nei he hìtori taihara roa, à, me te whaiwhakaaro ki te teitei o te pāpātanga mauhere, inarā o te iwi taketake. Ka whakamātauria e tēnei tuhinga he ariā e whakaahua ana he minenga whakaari te kiriaro ehara i te whanake whakatipu - te tirohanga matua a te haumaru hinengaro. Koia nei ka horaina atu he paku kōrero whakapapa mō te kiriaro mai i te tīmatanga o te rautau ruatekau, e whakaatu ana i te āhua o te panoninga o te kiriaro, kaua i roto i tirohanga takitahi noa iho, engari i waenganui o ngā reanga o te whakapapa o te hapori Te Uru. Ka whakamahia tēnei tirohanga hei whakamārama he pēhea i whanake ake ai he "kiriaro taihara" mai i te mauheretanga, ā ka mau hei āhua/momo mōna ake i roto i te wā o te ao ōhanga whānui, ā, me te take kāore e aro ake ki ngā mahi whakaoranga hinengaro. Mai i ngā mahi a Whaukarata, Rōhi, me Pātara, arā atu, ka whakaarahia ake te ariā 'whakaataatahanga whakahaurangi”. Ka tūhurahia te mahi o te riri hai whakatāokenga pākarukarutanga. Ka whakaputahia ètahi whakaaro mō te kaha rahi o te nui rawa akehanga o te kanohi iwi taketake kitea ai i roto herehere tērā ki tō te iwi whānui.

\section{Abstract}

Beginning with the experience of working with men in prison and others who have considerable prison experience, all of whom have long criminal histories, and considering Aotearoa's relatively high rate of imprisonment, particularly of indigenous people, this paper attempts to describe a theory of self as a performative assembly, rather than as a developmental achievement, which is the dominant view in psychotherapy. In doing so, a brief history of the self from the beginning of the 2oth century is presented, illustrating how the self changes, not just in an individual subjectivity, but between eras in the history of Western society. This perspective is used to understand how a "criminal self" might develop as a product of incarceration and as a natural extension of the self in the neoliberal era, and why it might prove resistant to psychotherapeutic intervention. Drawing on the work of Foucault, Rose, and Butler, among others, the concept of "intoxicating performativity" is introduced. The role of anger as an antidote to fragmentation is explored. Some thoughts are added about why indigenous people are overrepresented in prison compared to the population at large.

Manning, S., \& Nicholls, D. (2020). The assembly of a criminal self. Ata: Journal of Psychotherapy Aotearoa New Zealand, 24(2), 43-61. https://doi.org/10.9791/ajpanz.2020.11 
Key words: Self, crime, prison, Foucault, performativity, identity

\section{Prologue: Stories from Prison}

For some years I have been visiting a prison about once a week to offer funded therapy in relation to histories of historical sexual abuse. On one occasion, it turned out that a man whom I was due to see was no longer in the prison - he had been moved to another facility. The officers were helpful, offering to bring the next man's appointment forward. One officer made a joke. He pointed to the men in the visitors hall, talking with their visitors. They were all wearing the same one-piece garment, a neck-to-ankle suit of brightly coloured heavy cotton, zipped at the back and fixed at the neck with a tie that could only be removed with clippers. He said, "don't worry, look, they're all the same, just pick one, any one, they are all the same."

Over the next few weeks I became more observant, and I saw that actually, in many ways, men in prison do appear to be the same. There is a familiar rolling walk, a tone of voice, a way of holding the head, a way of talking, a language, gestures, a way of sitting, and, perhaps most important, what seemed to be a sort of pride. I began to ask, what was I witnessing? What had that clumsy, poor-taste joke brought to my attention? This is the story of the man in the orange suit.

We are talking in a room in a prison, one of four along one side of a hallway. Each has one glass wall, beyond which visitors and staff walk past while uniformed officers watch from their station across the hall. There is a camera in the room's ceiling, constantly recording the scene, and clipped to my belt I am wearing a small alarm button. Down the wide corridor is the main visiting hall, with its $5 \times 6$ grid of low round tables and stools, all bolted to the floor, at which are sitting men in one-piece bright orange suits, one per table, with their visitors, mostly parents, partners and children. The scene is observed by at least two officers who may or may not be wearing cameras.

The man with whom I am talking, and have visited weekly for almost a year, has a history of violence, drug use and organised criminal activity, and has been surrounded by these things since early childhood. There is physical and sexual abuse and considerable neglect in his early life.

We are discussing his forthcoming appearance before the Parole Board, a body appointed by the Attorney-General to consider risk and which in this case will set a date and prescribe some conditions that will apply upon release. One condition will be that this man does not reside, or associate with, his partner. Both he and his partner, whom I have met, are resolutely opposed to this condition. I asked whether he will be represented at the Parole Board, if he will plead his case.

The significance of his answer only began to dawn on me after I had left the prison that day and was on the highway driving back to the city. Meanings, created as they are from successive readings of a text, are still emerging.

What he said, was, "Fuck no. I am going to ignore the conditions. Then I'll get breached and do another three months, then I'll be released without conditions. I'm not going to spend fucking two grand on a lawyer when I can be completely free in three months. Fuck that.” It might have been then, or perhaps later, that he added, “Seán, you don’t understand. There are two worlds out there, and in mine, I am normal." 


\section{Some Background Data}

Reported crime in Aotearoa has been declining, slowly but steadily, as it has internationally, for several decades (data compiled from Newbold, 2000, 2016; Pinker, 2012; Stats NZ, 2020). When corrected for the increasing population, the decline is gradual, but clear. However, since 1950, our prison population has been rising. In the first 18 years of this century, it almost doubled, from 5,500 to 10,500, in round figures. A quick calculation will show that this rise is $62 \%$ faster than population growth. The numbers of Māori, who are between $51 \%$ and $52 \%$ of the prison population, rose by a factor of 1.9, while the numbers of Pākehā rose by a factor of 1.7 (extracted from Johnston, 2020).

Looking at our rates of imprisonment relative to other OECD countries, it is clear that we imprison a lot of people relative to other nations. At the top of that league table is the United States, where about 650 people per 100,000 of population are incarcerated, but they are out on their own, with their nearest rival, Turkey, at just over half the US rate. They are followed by Israel and Chile at just over 230, and Aotearoa/New Zealand, at over 200. For further comparison, another 31 countries imprison less that we do. The UK, on average, has a bit more than half of our rate, though the figures vary widely between England/Wales (139), Scotland (150) and Northern Ireland (76). Most of the rest of Europe comes in at less than 100, with, for example Germany at 77, the Netherlands at 61, and right down at the bottom of the table, Finland 51, Japan 41 and Iceland 37. Even allowing for cultural differences, these figures suggest not just different demographics but very different responses to crime. It is difficult to believe that our crime rates are double those of the UK or Germany, so, while a discussion of trends in imprisonment and of crime in Aotearoa is tangential to the purpose of this paper, for the time being we can note that we appear to favour imprisonment, and particularly the imprisonment of indigenous people.

Why this is, and what makes an apparently liberal society confine so many of its population, is unclear. An analysis of trends in crime and punishment and associated legislation would undoubtedly illuminate just how this happens, but the why is still likely be a mystery, particularly when the comparison with other OECD countries is considered. For instance, it's clear that rates of imprisonment do not parallel rates of crime within Aotearoa, so it seems unlikely that it would be the case between countries. To approach these questions, we must consider what environment of discourse produces such an apparent anomaly.

This paper necessarily narrows the focus of interrogation, to condider some of the effects of imprisonment, with particular reference to the concept of the "self" - a central idea in psychotherapy. To do so it may be useful to begin with a historical context.

\section{A Brief History of the Self}

This section takes a look at the background of the idea of the self, prior to returning to crime via the idea of a criminal self.

Brett Kahr, writing in 2015 about the influence of John Bowlby on the treatment of children, describes the late 19th-/early 2oth-century treatment of the child as an object. For instance, campaigners aiming to improve conditions in workers' homes were certainly concerned for children but they confined themselves to improving physical conditions (Kahr, 2015). The common response to behavioural problems in children often involved 
what might seem to us brutal treatments. Night terrors were treated with bromide, and it was recommended that those who walked in their sleep be tied to their beds. Powerful drugs, including hypnotics and opiates such as laudanum and apomorphine, were used to treat childhood hysteria, which was regarded as an inherited "cerebral affliction" and which covered a wide variety of symptoms and presentations. Kahr provides a quote from Dr. Edmund Cautley, a senior physician at London's Belgrave Hospital for Children: "Intentional neglect is advisable in convulsive affections, and indeed for most symptoms" (p.301). Bed wetting was often treated with electric shocks to the perineum or by means of an electrical probe inserted into the urethra, and with bladder massage per rectum (Kahr, 2015). There is little sense that the subjective experience of children, so important to us today, was of any importance at all.

As late as the 1930s, medical literature contained almost no information on how to treat psychological disturbance in children. Winnicott's (1931) Clinical Notes on Disorders of Childhood, which suggests that many apparently physical disorders in childhood could be explained as anxiety and depression, excited considerable antagonism among his medical colleagues, and when Bowlby began writing prior to the Second World War, he reported that most colleagues completely rejected his ideas. His two early hypotheses, that hysteria was not an organic but a psychogenic condition, and that separation was a key element in childhood disturbance, were mostly met with derision.

Many of Bowlby's contemporaries regarded any expression of ordinary kindness towards children as unhelpfully indulgent. As Bowlby reminisced, "You'll spoil him, you'll spoil him" was the regular cry. (Kahr, 2015, p. 301)

In Aotearoa, popular wisdom on the treatment of children was dominated by Truby King's (1940) Feeding and Care of Baby, at the time a boon to women who found themselves caring alone for a child, but from a 21st century perspective, quite uncompromising in its treatment of the child as a kind of unruly body in need of discipline. Feeding was on a strict régime and forbidden at night because it was the cause of night crying, which was to be ignored. Cold baths were recommended as the child grew older (p. 39), and "dawdling" in the bath was not to be allowed. Toileting was particularly important, to avoid constipation and the resulting irritation from worm infestation, leading to the horror of masturbation (p. 219).

The child's feelings are irrelevant; its character is developed through discipline and strict training. Despite the efforts of Winnicott and Bowlby, despite there having been systematic attention to the psychological needs of children among psychoanalysts since Hermine von Hug-Hellmuth published in Vienna in 1914 (cited in Kahr, 2015), and despite the work of Anna Freud and Melanie Klein in London in the 1920s (Young-Bruehl, 1988), the self as a product of rigid discipline was a dominant discourse for at least the first half of the 2oth century in European and English-speaking cultures.

Philippe Ariès' (1960/1962) Centuries of Childhood: A Social History of Family Life expands on the way the dominant view of childhood has changed. In Ariès' view, today's long childhood is a recent development. Previously, at best, young children who survived infancy were a source of joy, but from the age of between 5 and 7 they became workers, bringing 
income to the family. Childhood was over; they were little adults. Outside a very small group of psychoanalysts, whose views were treated with profound suspicion by mainstream medicine and psychology, there seems to have been no common construct resembling the sense of self as based in childhood experience, apart from character as a consequence of discipline, as it became commonly conceived later in the 2oth century (for instance, Stern, 1985).

In the years after World War II, a change in popular discourse appears to have taken place in Europe and the English-speaking world. Psychoanalytic ideas about child development began to attract attention beyond the narrow and hitherto isolated community of psychoanalysts and social workers who had been its adherents up to that point. Bowlby's Child Care and the Growth of Love was published in 1953, and by about 1960 a noticeable shift in popular views of the self is evident. "Humanistic" schools of psychotherapy began to popularise the psychodynamic developmental narrative, and although there was considerable deviance from Freudian orthodoxy, the legacy was often acknowledged. Berne's (1961) Transactional Analysis in Psychotherapy and Games People Play (1968) were readable and even at times humorous, and Fritz Perl's (1971) Gestalt Therapy Verbatim described a kind of therapy that lay readers could understand. There developed an intense interest in listening to each other. Jacob Moreno's psychodrama and the encounter group movement, alongside its psychoanalytic big brother at the Tavistock Institute for Human Relations in London (Bion, 1961) provided a uniquely egocentric and at times dramatic experience, in which people's inner life became interesting.

When Bowlby published the first of his three-volume series on Attachment and Loss in 1969 , it seems the world was ready for it. The self was becoming, in popular literature as opposed to that circulated among a small group of psychoanalytic initiates, something that could be understood in terms of past relationships, and there was the tantalising possibility of changing it voluntarily in whatever direction one wanted. There were winners and losers, and everybody could become a winner.

By the time Daniel Stern published the first edition of The Interpersonal World of the Infant in 1985, Bowlby's (1969, 1973, 1980) three-volume magnum opus was complete and a watershed had been reached. The early experience of children was where the template for the adult self was constructed. The literature on attachment and the development of a sense of self from the perspective of relationship and from a neurological point of view developed rapidly, in volume and complexity. Psychological difficulties in adulthood became the consequence of anxious and disorganised attachment in infancy, and of the impact of trauma (for instance, Antonio et al., 2017; Fonagy, 2001; Fonagy et al., 2002; Main \& Hesse, 2001; Schore, 1994; Siegel, 1999, 2012; Stern, 1998). The self was seen as coherent or fragmented, connected with secure or anxious attachment schema, and ultimately, if things go reasonably well, as agentive (Knox, 2010).

Similar developments can be seen in relation to another psychological construct, that of stress (Ogden, 1995). Early in the 1900s, the individual was a passive responder to external events, just as the addict was the unfortunate victim of a hereditary disease and the hysterical child carried the burden of its inherited defects. From the 1930s, stress resided within a stimulus/response framework, in line with the emerging behavioural psychology, and then, as Jane Ogden (1995) puts it, "a more animated object began to appear in psychological 
theory."(p. 410) Cognitions and individual processing capacity entered the formulations. George Kelly (1955) developed personal construct theory, Albert Ellis (1975) was working on rational emotive therapy, and a little later Aaron Beck's name became associated with cognitive therapy, to become known as CBT (for instance, Beck, 1989). All of these involved an interaction. The self, now an individualised entity, a consequence of experience, with considerable self-determining power, interacted with the environment, with the stressor, principally by means of thinking. It was a two-way conversation, between mental representations and stimulus characteristics. In 1977, Lazarus (cited in Ogden, 1995) redefined stress as a transaction between the individual and the external world, and by the time we get to the 21st century, our wealth, our wellbeing, our happiness, our physical survival, our longevity, our feelings, thoughts and behaviour and our stress are all the consequence of the actions of our agentive selves (P. Kelly, 2013).

Similarly, in parallel with psychological constructs such as the self and stress, crime goes through several transformations, from being a consequence of heredity or defective character formation, to being a consequence of structural factors, such as poverty and anomie to being "a kind of behavior grounded in culture, ... which can be transmitted through social learning” (Melossi, 2008 , loc 224, 1520), that is, a consequence of one's childhood, to being a choice in the 21st-century neoliberal economy, where the self is a project, a work in progress.

\section{The Developmental Hypothesis and Its Coming Apart}

This idea, that our selves, our identities, our sense of who and what we are as individuals, is a consequence, or an achievement, of our relational history, especially our history early in life, I am calling the "developmental hypothesis." It can be regarded, in the language of Michel Foucault, as a discourse, or as a discursive environment (for example, Foucault, 1966/1989, 1981).

Jeremy Holmes (2020) suggests that psychotherapy is a practice in search of a theory. I suggest that for those of us who work immersed in this terrain occupied by the developmental hypothesis, this practice is based on a series of ideas that we are very fond of, and around which the bulk of our literature has developed.

1. We can view the past through the eyes of the present, judging events and past behaviour according to our current morality, in the service of reconstructing narratives about the past that make sense today. The idea that we can reconstruct the past at all relies on the assumption of a consistency of experience and discourse surrounding the self - for instance, if a child experienced that today, it would feel like this, and therefore we can understand the impact on the development of the person of past events. Yet on closer examination, this reasoning is flawed. We can construct the past in the present, of course, but not as it was, only as it seems to us through the eyes, the discourse, of today, as if that had happened now.

2. We see the development of our selves, and the selves of our clients, as continuous, a process of accretion, one thing building upon another, the structure ruptured by trauma and repaired by mutuality in relationship. While this view is backed by almost 
all literature in the field of psychotherapy, it seems based on a subjective sense of continuity, one of the characteristics of the self (Siegel, 1999). Upon waking up, we believe we are the same person who went to sleep, that our memories and habitual feelings are familiar. There is a growing literature on how this occurs in our brains (for example, Damasio, 2011) but the mechanism remains something of a mystery. From the point of view developed in this paper, it is as though a massive literature has developed out of a subjective experience, possibly the most unreliable approach to defining an external reality.

3. Thirdly, we like to think that we are free, or that we can become so, that we can reach a state where we make decisions voluntarily, design our lives, work on ourselves, although this view is mitigated, among the more thoughtful practitioners, by two contradictory belief systems:

- that our choices are limited, circumscribed, scripted, controlled by an 'unconscious' that can never be known; and

- that there is a way out of the script, that something approaching autonomy can be achieved, and we use that title to describe the adult version of "secure attachment."

So we tend to see scripting, or the effect of a reified unconscious, as a part, or consequence, of a continuous sequence, a result of the circumstances of development, and we hold to the idea that psychotherapy can change the outcome of that sequence, providing the opportunity to create or improve what we term as autonomy, or agency (for instance, Knox, 2010).

When I began to look at what I am calling a criminal self, it was almost exclusively from the perspective of the developmental hypothesis. I was using the tools, the perspectives, the wisdom, the literature, with which I was familiar, which I had been studying and teaching for decades. I saw mannerism and gesture, I listened to histories with their emotional articulation, and I distilled what I was experiencing into attachment schema, life scripts, and the intersection of those scripts in the dramas that played in the room between us.

I saw ways of walking, tones of voice, and ways of using language; I noticed the effect on me of these observed phenomena and my response to them. I saw my warmth, my alienation, my disgust, my sorrow, my sympathy and the lack of it, and I abstracted from all of these transferential phenomena stories told in non-verbal ways.

All the tools of my trade were deployed. However, the more I saw, heard, experienced, and in particular the more I read, the less effectively these familiar tools served to guide me. The limited effect of psychotherapeutic intervention with habitually criminal men was painfully obvious, both in my experience and in the literature. The hubris I must confess to carrying concerning the role of a psychotherapist, worn like a garment, and with pride, began to show signs of wear, fraying a little at the cuffs and collar, a hem drooping, becoming a little tired and old, in tune, I could not help reflecting, with the body that wore it.

\section{Problematics of Individuation}

This argument therefore problematises the notion of individuation, or individuality, or self-agency, which is the basis of all cognitive-behavioural interventions and the hypothesised 
outcome of psychotherapy based on the developmental hypothesis, in all its iterations.

Attachment theory (for example, Wallin, 2007) is probably the dominant discourse in psychotherapy at present, backed as it is by a lot of research and clinical expertise. Here individuation is one end of a bipolar construct, the other side of which is represented by connection, in its extreme form, in the sense of enmeshment. Each position in this relational space is associated with an "attachment schema." Each extreme is associated with a certain kind of pathology in relationship - "dismissing attachment," associated with individuation, and "preoccupied attachment" at the extreme of connection. On one hand I am detached from relationship and easily overwhelmed by it, on the other I am worrying about it, incessantly seeking reassurance. "Secure" or "autonomous" attachment lies in a kind of sweet spot between the two, where I can explore and connect in equal measure. This model presupposes, in the autonomous position where I am neither on the run from people nor drawn to them obsessively, the reality of personal agency, the ability to design our own lives.

The cognitive-behavioural model, deriving from the work of Aaron Beck, also presupposes agentive action. (To this extent we must regard CBT and psychodynamic models based on attachment theory, often juxtaposed in a hostile dialogue, as deriving from the same set of ideas in the modern era.) In the Corrections setting, where CBT is the intervention of choice in government-funded programmes, thinking is the target of intervention - learn to think differently, predict the consequences of your feelings and impulses, and you gain control of your life and need not get into trouble. In the psychodynamic model the target is attachment - achieve the balance point between individuation and connection and you will learn to control what you do next, and thus control the future. With habitual offenders, both approaches fail in about equal measure. The best programme offered in our Corrections system is the Special Treatment Unit Rehabilitation Programme (STURP). It achieves a $13.5 \%$ reduction in reconviction within one year. Drug treatment programmes in prisons, based on the same cognitive principles, achieve 6.8\% (Department of Corrections, 2018, 2019). Figures for psychodynamic approaches are not available, as it is not so systematically practised, but there are multiple references in the literature that predict a similar outcome.

The idea of self-agency as a consequence of a developmental sequence is so familiar, so much a part of the everyday work of psychotherapy, that it seems impertinent to question it, but there are other ways of seeing ourselves if we can stand a little to the side of our habits for a bit. In a Foucaultian analysis, as expressed by the British sociologist Nikolas Rose (1998, 1999), leaning on the philosopher Giles Deleuze, individuation, agency, and autonomous attachment, are aspects of being that are "enfolded" from the discursive world we inhabit. We are encouraged to believe in ourselves and our agentive capacity, but it appears as a function of late capitalism, an achievement of the discourses of the neoliberal era, rather than a real freedom. The journalist and essayist Jia Tolentino (2019) puts it succinctly:

the underlying idea that would drive twenty-first-century technology and culture the idea that ordinary personhood would seamlessly readjust itself around whatever within it would sell. (p. 39, emphasis added)

As Peter Kelly (2013) puts it in his book Self as Enterprise, we are encouraged to act as a "Me \& 
Co., selling ourselves on the marketplace” (loc 195). Thus one of the subheadings within the current project is to problematise the individuality of the offender, as an aspect of the criminal self. What is the project of such a self, and what within it sells?

Foucault (1966/1989) asks, in the introduction to The Order of Things,

What conditions did Linnaeus (or Petty, or Arnauld) have to fulfil, not to make his discourse coherent and true in general, but to give it, at the time when it was written and accepted, value and practical application? (p.xiv)

My question can now be modelled thus: what conditions does a young male experiencing the effects of imprisonment have to fulfil to give his discourse value, meaning and application? The provisional answer is a description of the technologies of the criminal self, the criminal identity.

I cannot just ignore the developmental hypothesis and go off into a world of postmodern uncertainty (after all I am a psychotherapist), but neither can I uncritically accept it any longer. One tries not to fall into the trap of thinking that one view is better than another. They belong to different eyes, different eras, different bodies. On a theoretical level, it may still be useful to think that we possess qualities that are best considered from the developmental hypothesis - overall level of arousal, for instance, and perhaps some specific triggers for hyperarousal. This is not to say that the developmental perspective is true, only that it is available and at times convenient. The self, on the other hand, the way we construct ourselves from within, the way we describe ourselves, our attractions and alienations, our specific talents, interests, preferences, tastes, the minutiae of how we act in relationship, our chosen occupations, our belief in ourselves, or the lack of it, while driven by arousal patterns, in the detail of their iteration, owe far more to the world of discourse. In Foucault's analysis of discourse, we express dominant themes in the world of ideas that we do not notice but are like the air around us. In Rose's $(1998,1999)$ sociology, we invent ourselves from moment to moment. In Judith Butler's (1990, 1993) analysis (though she writes of gender and sex, it works for other aspects of identity), we perform ourselves.

Before returning to criminality, it is worth noting at this point an opposing argument, put beautifully by Carol Worthington in a personal communication:

in my ... view you confuse thinking with material change. The self as I see it is not a matter of Western words and thinking, it's a very real embodied thing which can be felt, not just thought of. I'd fully agree that criminals think they've found their real self, but that's a far cry from the changes Winnicott had in mind, changes that developmentally bring about fundamental changes in the personality. ... "Solid" is the key word, and this is why I agree with Winnicott that there is a real embodied self which can be felt and related to.... I think your criminals have adopted the prison-self as a substitute for having a real self in the Winnicottian sense.

There is no doubt that Winnicott's formulation of real and false self, and Worthington's identification of the self as embodied accord much more closely with our phenomenology, our experience of ourselves. I argue simply that phenomenology, while certainly the most 
popular and intuitively believable way of building models of ourselves, runs into problems when it becomes defined as truth. I am as prone to nostalgia as anyone. Just as Kristof Koch (2012) writes of a neuroscientist's experience of letting go of religion but still feeling attached to cathedrals (p. 165), I have had to acknowledge that, though the church of developmental theory still holds my affection, I can no longer worship there.

From the views of the self as expressed by Foucault, Rose and Butler, identity, self, soul, rather than being seen as an achievement of relational development, is defined as a subjectivity, an achievement of discourse based on what we 'enfold' from the environment, which for all of us consists of whatever ideas are on sale at the moment, and whatever sells.

\section{The Criminal Self}

Rose (1998) uses a concept from Deleuze, the idea of "folding." It is as though we are able to take things from our environment and enfold them into ourselves, in such a manner that we imagine that they are a natural part of ourselves:

If, today, we live out our lives as psychological subjects who are the origins of our actions, feel obliged to posit ourselves as subjects with a certain desiring ontology, a will to be, it is on account of the ways in which particular relations of the exterior have been invaginated, folded, to form an inside to which it appears an outside must always make reference. ... This diagram of the fold describes a figure in which the inside, the subjective, is itself no more than a moment, or a series of moments, through which a "depth" has been constituted within human being. (p.188)

The narrative, or identity, is regarded, is felt to be natural, but the self, and in particular the criminal self, seems largely an assemblage of current ideas rather than a developmental achievement, and while it can certainly be formulated as Worthington does, as a thought entity, disguising a real self, it is precisely its embodied nature that makes it so functional, and, as recidivism data suggests, enduring:

styles of walking, dressing, gesture, expression, the face and the gaze, body hair and adornment - a ... machination of being in terms of the look that operates ... between the outer and the visible and the inner and invisible. (Rose, 1998, p. 195)

Now we can return to the prison, to the walk, the voice, the tone, the look, the prisoner's manner of sitting, the way the head is held, the way the arms swing at some distance from the body, gestures as though designed to take up as much space as possible. All these displays seem to have been enfolded, borrowed from the surrounding field of discourse. Allied with these gestures are narratives with themes of battle, trickery, mastery, and cruelty; of pleasure taken rather than found; of training and hard physical work; of drug and alcohol use; and of gangs which are often described as whānau. Women are objectified, and given the definite article - the missus - and violence toward them is legitimated, even considered essential.

All of these stories are accompanied by ways of feeling, ways of keeping emotion within a narrow range of pleasure and anger, and by ways of thinking, of clear ideas of right and 
wrong, albeit somewhat distant from their equivalents in mainstream culture.

In prison the small, repeated, everyday interactions, the body language, the humour, the tone of voice, all build and reinforce a series of role stereotypes which are gendered and class specific. These are practised every day in postures, ways of walking, various roles taken, for instance, when joking, in the types of joke favoured, in ways of carrying the head, styles of eye contact, silences, and expressive ways of not communicating (Manning, 2019). These styles are alienating to others outside the criminal culture, and these selves are alienated from the mainstream, but they are coherent. To use a neoliberal concept, they sell.

These "technologies of the self," to use a term from Foucault (1982/1994), these ways of constructing identity, can be seen as ways of doing crime, just as we talk of doing gender (for example, Butler, 1990; Ranger, 2015), or doing health (Saltonstall, cited in Courtenay, 2000).

The narrative feels as though it is imbued with, and created by, choice. The way memory and personal narrative play together is important. The narrative is what we remember, not the event, not the experience but the story. There is quite a lot of evidence around the link between talking and memory (for instance, Leichtman et al., 2017). Children remember events that they talk with parents about, and the more open-ended the parents' style, the more descriptive their language, the better the child's memory. Talking about experience embeds memories of it, but the memories are not of the experience, they are of how it is talked about. We remember the story.

As Tolentino (2019) put it,

In my journal, ... I ... worry that I'm more interested in narrative consistency than anything. I worry that all this self-monitoring has made me ... too conscious of what "Jia" would do in this situation - that I'm in danger of becoming a character to myself. ... I forget everything that I don't need to turn into a story. (pp. 45-47)

The prisoner talks with other prisoners, each conversation embedding the narrative in memory. He walks in the way he has enfolded walking, talks as he has enfolded talking, in the same tones as others, with the same vocabulary. His stories about women, about children, his attitudes towards health, toward danger, toward death (for this is the most at-risk group) are all embedded in a common narrative. Perhaps most importantly, he has enfolded a way of dealing with, of expressing, anger which not only validates it, but makes it the centre of his being and brings with it recognition, acceptance, membership and respect. The danger it represents - of injury, of further imprisonment - is irrelevant, as the self now orients itself toward danger, toward prison. Each action, each practised gesture serves to reinforce the inner experience, the copied movements working to create coherence among the several elements he has taken into himself.

\section{Intoxicating Performativity}

I have already mentioned Judith Butler, who provides an alternative view of the construction of identity with parallels to Rose, and who further details its embodiment. Identity, specifically sex and gender in Butler's writing, is performed. It is not simply something that is acted, otherwise, as Butler (1993) points out, we might wake, peruse the closet for an 
identity of choice, wear it for the day and pack it away at night. Clearly, felt identity cannot be worn like a garment. Moreover, it is not the subject that chooses the identity, the subject is created by the identity, which is a consequence of relations of power. (In the context of prison this is the power/knowledge complex of the Corrections industry.) It is the identity that enables the subject to think, to act, to make sense. Without it, one is lost, one does not exist as a somebody. And it is the function of the criminal identity to create a somebody. To use Butler's words,

[identity] not only functions as a norm, but is part of a regulatory practice that produces the bodies it governs, that is, whose regulatory force is made clear as a kind of productive power, the power to produce - demarcate, circulate, differentiate the bodies it controls. (p.1)

Further,

performativity must be understood not as a singular or deliberate "act" but, rather, as the reiterative and citational practice by which discourse produces the effects that it names. (p. 59)

What is performed must be repeated, and it must be an iteration of a norm. Performativity is the way that discourse produces its effects.

It is not "free play nor theatrical self-presentation" (p.60) and it is not performed by the subject, it is what "constitutes the temporal condition for the subject." It is "a locus of discursive production" (p. 70). If identity is regarded as an achievement of discourse, then performativity is the tool that crafts it.

This is difficult - we are so used to thinking that we act to produce, or at least to modify, the world, but in this formulation the situation is reversed, as the world acts to produce us. Butler (1990) refers to gender as "the repeated stylisation of the body" (p. 45) and to "identitarian logical systems" (p. 53) which surround the subject, providing, as Rose might say, material to be "enfolded," or in Butler's term "performed" and thus to be felt to be the self, or a formative part thereof.

Butler (2015) has also written about assembly in the sense of assemblies of people, particularly in a political sense, as in "we, the people." Her assemblies tend to be virtuous assertions of rights, demonstrations, protests, but her formulation works well for less obviously virtuous assemblies such as the population of a prison, where performativity in non-verbal mechanisms of speech and of the body make the presence of the assembly, the larger body, or what Butler calls the "plural subject" (p. 177), felt. It may not be in the service of asserting the rights of the members of the assembly but it can certainly be regarded as a political act, an assertion of the right to an identity that is at least felt to be more adopted than assigned. She describes how we, the people is "spoken or enacted" (p.169) in a way that brings to mind the community of inmates in their non-verbal performative enactments in relation to officers, specialists, and each other. Here we can see the criminal identity as a form of plural as well as singular subject, or an "assembly," for increasingly those terms, the "assembly of the self" and the "self in assembly," appear now to move together, apparently 
attempting to fuse. In the way that assemblies of people can act politically, there is something intoxicating about the inmate assembly, an intoxicating performativity that helps us understand the permanence of the subjectification, why it is not easily modified.

This is one of my favourite quotes, from a hero of my youth, or possibly from another cathedral:

In a capitalist system, most people live in an invisible cage. For example, there you accept the myth of the self-made man, but don't understand that the opportunities of most people are determined by forces they don't even see. (Attributed to Ernesto "Ché" Guevara de la Serna, 1964, during a visit to the UN on behalf of the Cuban government, as quoted in Soderbergh, 2008).

The metaphor of the cage is apt, and perhaps refers to a term used by Weber (1930) stahlhartes Gehäuse (steel-hard housing) - translated as "iron cage." Weber was referring to the effect of materialistic culture, but he appears to have been prefacing a postmodern view that would wait 40 years after his death to emerge. These models of performance and of enfolding, as practices or technologies of the self, go a long way to explain the sameness in physical presentation among inmates, and provide detail and method to the observations of Weber and Guevara mentioned above. The cage, though, is not an imposed, coercive technology, but an achievement of a discursive environment, perhaps a surface of emergence wherein one can examine performative practices, the process of enfolding, and the assembly of an identity with a considerable sense of agency.

A 21st century neoliberal self is, as P. Kelly (2013) suggests in the title of his book, an enterprise:

At the start of the twenty-first century, in the globalised, risky labour markets of the over-developed economies, the cultivation of the self as an enterprise is the life-long activity that should give meaning, purpose and direction to a life. (loc. 149)

\section{Resistance, and the Inversion of Morality}

Disappointment, neglect, and abuse are common among prisoners, but in prison one is not alone, one is in the company of others, where mistrust, disappointment, vigilance, and the expectation of being ignored in society, are all talked about in stories of betrayal and violence, of vendetta, vengeance and heroism. The story is tied together with anger. So you ignore me? Just wait, you'll see. Now the script, instead of being an oppressive, depressing, burdensome rumination, fragmented, random, and undermining, has become coherent, the basis of a story that can be shared with pride, the foundation on which a sense of self can be built. If he is unsure how to be angry, if he is inwardly focussed and melancholic, there are plenty of people who will show him how to focus outward, how to have an impact. If he fights, it does not matter so much if he wins or loses; he is respected for fighting. He now has something previously out of reach - a career, someone to be. This is how the "abstract machine," a concept from Deleuze and Guattari (1988), the prison, works its transformation: 
In Foucault's analysis, "discipline" was the name of a kind of abstract machine that was immanent in the prison, the school, the barracks. (pp. 66-67)

(Discipline here refers to Foucault's 1977 use of the term, meaning the effect of the "carceral," the entire system created around the function of incarceration, including its effect in producing docility in the population at large.)

Thus is created an angry, psychopathic, antisocial, remorseless, nihilistic, but coherent subjectivity out of fear, fragmentation, melancholy, and self-destruction. The anger will feel real, it will be his anger, in keeping with his story, a story that has been transformed from that of a victim to that of a perpetrator, so that morality is turned on its head.

In a 1966 addendum to his 1943 treatise on The Normal and the Pathological, George Canguilhem, who acted as rapporteur on Foucault's 1960 thesis, Madness and Unreason (Roudinesco, 2005/2010, p. 21), writes, apparently influenced in turn by Foucault:

A norm draws its meaning, function and value from the fact of the existence, outside itself, of what does not meet the requirement it serves. (Canguilhem,1966/1991, p. 239)

Behaviour defined as criminal therefore gives meaning and function to the norm, and in this case, also to the law. Canguilhem (1966/1991), described by Louis Althusser as "an anthropologist who goes into the field armed with 'a scrupulous respect for the reality of real science”" (Rabinow, 1994, p.11), also suggested that:

Every preference for a possible order is accompanied, most often implicitly, by the aversion for the opposite possible order. (p. 240)

but a few lines later, he adds that there can be an inversion:

as the ethical norm, where sincerity prevails over duplicity, can be inverted into a norm where duplicity prevails over sincerity. (p. 240)

P. Kelly (2013) makes a similar observation:

And what of those who, for whatever reason, cannot or will not inhabit this world? Rejection of it might seem a reasonable alternative, and the most available kind of rejection in the surrounding world of discourse will be the most obvious choice. (loc. 300)

Anger transforms a relation of self-to-self such that something felt to be ungovernable, outof-control, at the mercy of others, becomes something defining, a view of self that, within the cultural discourse that achieves it, is positive. It brings rewards, it indicates a future, it has company, mentors, a career, it gathers together the fragmentary experience of being into a whole. It may seem from a mainstream perspective simplified and inflexible, but it is coherent, it is a sense of being someone, it is a governable, and it sells. 


\section{The Criminal Identity Machine, Indigenous People, and the Expert Rationale}

There is a lot of literature describing the dehumanising power of institutions, famously Goffman's (1968) Asylums, published 3 years after Foucault's (1965) Madness and Civilisation had appeared in English. Literature on "labelling theory" (Becker, 1973; Kitsuse, 1962) in relation to crime and psychiatry, showing how people will respond to a labelling system by adopting the label and acting the prescribed role, emerged at about the same time, followed in the 1980 by what became known as the radical psychiatry movement (for example, Castel et al., 1982). Meantime Foucault (1977) had published his Discipline and Punish.

All of these accounts tend to situate the power/knowledge complex which drives the institutional system in a top-down manner, as though the institution, with its professionals holding the knowledge that gives it credibility, is doing something to the inmates. What is described here appears more as a consequence of the same discourse that creates the carceral, but as a kind of resistance. There is a considerable literature on subjectification, on the way the subject, or, to the psychotherapist, the self, is achieved via discourse (for example, Foucault, 1981; Rose, 1998). Prompted by a bad joke in a prison that drove a more careful observation, here we appear to find a subjectivity with a script that has the characteristics of an assertive, agentive enterprise with its own objectives and methodology, in an arena where mainstream psychotherapy theory sees a pathology, a distortion of self.

Both the man in the orange suit and I knew that the system of discourse that surrounded us, an iteration of the cage, would continue to provide rationale for things as they were. The Parole Board would meet, would set its conditions, and he would be released, re-arrested, and released again.

Foucault (1973/2015), in a lecture at the Collège de France, describes how a certain rationality is constructed around the persona of the expert, who becomes, in the rest of the world, the arbiter of "rationality." The expert in this case is represented by the Parole Board, who would carry out their duties conscientiously and might never know about the resistant subjectivity with which they were faced, since his plan would not involve appearing before them a second time.

It is not surprising, then, that the prison population has risen so rapidly with the neoliberal economy. As to the out-of-proportion presence of indigenous people, one must suggest that the dominant mainstream universe of discourse is not suiting them very well. It may be more difficult for the colonised to enfold and create the neoliberal self, perhaps because neoliberal Western economic policy is a colonising force. P. Kelly (2013) provides an instructive comment on ethnicity that sheds light on the high Māori prison population:

In many respects the self as enterprise does not have a gender, or an ethnic background, or a particular age, or a specific geographic location. Though this may not be entirely accurate. It is possibly more accurate to imagine that gender neutrality assumes masculinity. That no ethnic background assumes "whiteness" ... no age barrier means a productive, enterprising adulthood that runs from the mid 20 s to the mid 40s. That having no place in effect means ... cosmopolitan, post-industrial urban geography. (loc. 360-362, emphasis added) 
The population of our prisons almost doubled in the first 18 years of this century, from 5,500 to 10,500 (Devlin, 2019). About $52 \%$ of inmates are Māori. We seem very fond of incarceration, particularly when it comes to indigenous people.

These figures suggest that there is some kind of self-perpetuating social machine at work, a criminal identity machine. It seems as though prison is a place to learn to hold your head up high as an "ordinary decent criminal," to borrow a movie title (O'Sullivan, 2000). Here you can be someone, when you have never been anyone in the past. Here the abuse, the violence, the neglect, the alienation that lie behind the actions that landed you in prison (sexual and family violence in childhood is reported by $56 \%$ of men and $75 \%$ of women in prison; Bevan, 2017), all the forces that oppressed you are cancelled out, and, paradoxically, because you are actually confined, you are, for perhaps the first time, someone. You have a job. You have a peer group. You have mentors. You have a future.

Thus the processes that create the agentive self as enterprise in the neoliberal, individualistic world, operate in prison to create the subjectivity that must be imprisoned.

\section{References}

Antonio, A., Stefano, C., \& Jaak, P. (2017). The affective core of the self: A neuro-archetypical perspective on the foundations of human (and animal) subjectivity. Frontiers in Psychology, 8 . Ariès, P. (1962). Centuries of childhood: A social history of family life (R. Baldick, Trans.). Jonathan Cape/ Vintage. (Original work published in 1960)

Beck, A. T. (1989). Cognitive therapy and the emotional disorders. Penguin.

Becker, H. S. (1973). Outsiders: Studies in the sociology of deviance. Free Press.

Berne, E. (1961). Transactional analysis in psychotherapy. Grove Press.

Berne, E. (1968). Games people play. Penguin. (Original work published in 1964)

Bevan, M. (2017). New Zealand prisoners' prior exposure to trauma. Practice: The New Zealand Corrections Journal, $5(1)$.

Bion, W. R. (1961). Experiences in groups and other papers. Tavistock.

Bowlby, J. (1953). Child care and the growth of love. Penguin Books.

Bowlby, J. (1969). Attachment and loss: Vol. 1. Loss. Basic Books.

Bowlby, J. (1973). Attachment and loss: Vol. 2. Separation. Basic Books.

Bowlby, J. (1980). Attachment and loss: Vol. 3. Loss, sadness and depression. Basic Books.

Butler, J. (1990). Gender trouble: feminism and the subversion of identity. Routledge.

Butler, J. (1993). Bodies that matter: On the discursive limits of sex. Routledge.

Butler, J. (2015). Notes toward a performative theory of assembly. Harvard University Press.

Canguilhem, G. (1991). The normal and the pathological. Zone Books. (Original work published in 1966)

Castel, R., Castel, F., \& Lovell, A. (1982). The psychiatric society (A. Goldhammer, Trans.). Columbia University Press.

Courtenay, W. H. (2000). Constructions of masculinity and their infuence on men's well-being. A theory of gender and health. Social Science e Medicine, 50, 1385-1401.

Damasio, A. (2011). Self comes to mind: Constructing the conscious brain. Random House.

Deleuze, G., \& Guattari, F. (1988). A thousand plateaus: Capitalism and schizophrenia. Athlone Press. 
Department of Corrections. (2018). Annual report, 2017-2018. Author.

Department of Corrections. (2019). Annual report, 2018-2019. Author.

Devlin, C. (2019, April 24). Prison population increases past 10,000 inmates. Stuff. www.stuff. co.nz

Ellis, A. (1975). RET [rational emotive therapy] abolishes most of the human ego (ED117638). ERIC. https://eric.ed.gov/?id=ED117638

Fonagy, P. (2001). Attachment theory and psychoanalysis. Other Press.

Fonagy, P., Gergely, G., Jurist, E. L., \& Target, M. (2002). Affect regulation, mentalization and the development of the self. Other Press.

Foucault, M. (1965). Madness and civilization. Vintage Books.

Foucault, M. (1977). Discipline and punish: the birth of the prison (A. Sheridan, Trans., 2247075, 1st American ed.). Pantheon Books.

Foucault, M. (1981). The order of discourse: Inaugural lecture at the Collège de France, 2 December 1970. In R. Young (Ed.), Untying the text: A post-structuralist reader (pp. 51-78). Routledge and Kegan Paul.

Foucault, M. (1989). The order of things: An archaeology of the human sciences. Routledge. (Original work published in 1966)

Foucault, M. (1994). Technologies of the self. In P. Rabinow \& N. Rose (Eds.), The essential Foucault: Selections from essential works of Foucault, 1954-1984 (pp.145-169). The New Press. (Original work published in 1982)

Foucault, M. (2015). Lecture 1, 3 January 1973. In F. Ewald \& A. Fontana (Eds.), The punitive society - Lectures at the Collège de France 1972-1973: Palgrave Macmillan, Kindle Edition. (Original work published in 1973)

Goffman, E. (1968). Asylums. Penguin.

Guevara, E. (2005). The Ché Guevara reader. Ocean Press.

Holmes, J. (2020). The brain has a mind of its own: Attachment, neurobiology, and the new science of psychotherapy. Confer Books.

Johnston, P. (2020). RA4502 prison mthly snapshots from 1983. NZ Department of Corrections Ara Poutama Aotearoa.

Kahr, B. (2015). "Led astray by their half-baked pseudo-scientific rubbish": John Bowlby and the paradigm shift in child psychiatry. Attachment, 9(3), 297-319.

Kelly, G. A. (1955). The psychology of personal constructs. Morton.

Kelly, P. (2013). The self as enterprise: Foucault and the spirit of 21st century capitalism. Taylor and Francis, Kindle Edition.

King, S. F. (1940). Feeding and care of baby: Whitcombe and Tombs.

Kitsuse, J. I. (1962). Societal reaction to deviant behavior: Problems of theory and method. Social Problems, 9(3), 247.

Knox, J. (2010). Self-agency in psychotherapy: Attachment, autonomy, and intimacy W W Norton.

Koch, C. (2012). Consciousness: Confessions of a romantic reductionist (16988538). MIT Press.

Leichtman, M. D., Camilleri, K. A., Pillemer, D. B., Amato-Wierda, C. C., Hogan, J. E., \& Dongo, M. D. (2017). Talking after school: Parents' conversational styles and children's memory for a science lesson. Journal of Experimental Child Psychology, 156(April), 1-15.

Main, M., \& Hesse, E. (2001). Attachment narratives and attachment accross the lifespan. Journal of the Americal Psychoanalytic Association, 48 . 


\section{The Assembly of a Criminal Self}

Manning, S. (2019). The prisoner's joke (Unpublished work).

Melossi, D. (2008). Controlling crime, controlling society: Thinking about crime in Europe and America. Polity.

Newbold, G. (2000). Crime in New Zealand. Dunmore.

Newbold, G. (2016). Crime, law and justice in New Zealand. Taylor \& Francis Group.

O'Sullivan, T. (2000). An ordinary decent criminal. Icon Entertainment International.

Ogden, J. (1995). Psychosocial theory and the creation of the risky self. Social Science and Medicine, 40(3), 409-415.

Perls, F. S. (1971). Gestalt therapy verbatim. Bantam.

Pinker, S. (2012). The better angels of our nature: Why violence has declined. Penguin Books.

Rabinow, P. (1994). Introduction: A vital rationalist. In F. Delporte (Ed.), A vital rationalist: Selected writings from Georges Canguilhem (pp.11-22). Zone Books.

Ranger, L. (2015). Doing gender as an offender: A criminological analysis of offender narratives, and the interrelationship between masculinities and child sexual abuse. Victoria University of Wellington. http://hdl.handle.net/10063/4773

Rose, N. S. (1998). Inventing our selves: Psychology, power, and personhood. Cambridge University Press.

Rose, N. S. (1999). Governing the soul: The shaping of the private self (2nd ed.). Free Association Books.

Roudinesco, E. (2010). Philosophy in turbulent times: Canguilhem, Sartre, Foucault, Althusser, DeLeuse, Derrida (W. McCuaig, Trans.). Columbia University Press. (Original work published in 2005)

Schore, A. N. (1994). Affect regulation and the orinin of the self: The neurobiology of emotional development. Lawrence Erlbaum Associates.

Siegel, D. (1999). The developing mind - How relationships and the brain interact to shape who we are. Guilford.

Siegel, D. (2012). The developing mind: How relationships and the brain interact to shape who we are (2nd ed.). Guilford.

Soderbergh, S. (2008). Ché - A revolutionary life. Morena Films, Warner Bros, IFC Films.

Stats NZ. (2020). Charges prosecuted against adults by offence type calendar year. http://nzdotstat. stats.govt.nz/wbos/Index.aspx?DataSetCode=TABLECODE7351\& ga $=2.224834842 .1078096961 .1587940379-32614769.1571437597$

Stern, D. (1985). The interpersonal world of the infant - A view from psychoanalysis and developmental psychology. Basic Books.

Stern, D. (1998). The interpersonal world of the infant (rev. ed.). Basic Books.

Tolentino, J. (2019). Reality TV me. In J. Tolentino (Ed.), Trick mirror: Reflections of self-delusion (pp. 34-62): Harper Collins. Kindle Edition.

Wallin, D. J. (2007). Attachment in psychotherapy. The Guilford Press.

Weber, M. (1930). The protestant ethic and the spirit of capitalism (T. Parsons, Trans.). Allen and Unwin.

Winnicott, D. (1931). Clinical notes on disorders of childhood. William Heinemann.

Young-Bruehl, E. (1988). Anna Freud: A biography: Summit Books. 


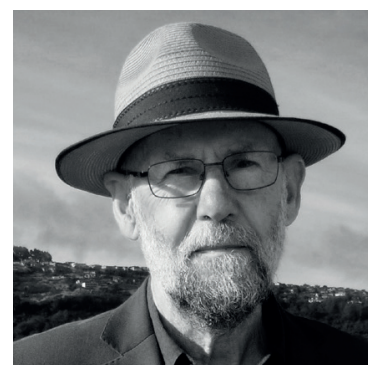

Seán Manning has been working with crime, addiction and violence in men for over 40 years, as social worker and psychotherapist. This paper arises from his doctoral studies on the assembly of criminality. Originally from Belfast, Northern Ireland, he has three adult children and two grandchildren. $\mathrm{He}$ has held a number of offices in professional associations and is a former president of the New Zealand Association of Psychotherapists but recently has been working on a social life and has almost overcome a tendency to be argumentative. His limited abilities with Māori and Spanish are a lot better than his command of Irish. His addiction to collecting musical instruments is almost under control though his ability to play them lags behind. He is interested in how psychotherapy works and what happens in the human brain in the construction and reconstruction of the self. His published work includes reports on the effectiveness and the essentially secular nature of psychotherapy, on antisocial behaviour, on the effectiveness of family violence programmes, and.a critical review of ideas about the unconscious.

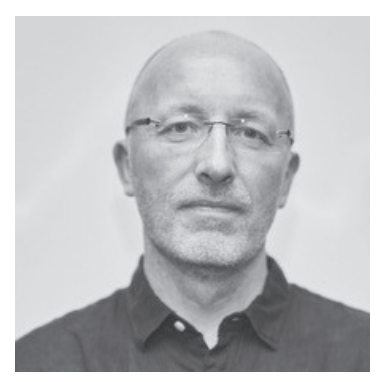

Dave Nicholls is a Professor of Critical Physiotherapy in the School of Clinical Sciences at AUT University in Auckland, New Zealand. He is a physiotherapist, lecturer, researcher and writer, with a passion for critical thinking in and around the physical therapies. David is the founder of the Critical Physiotherapy Network, an organisation that promotes the use of cultural studies, education, history, philosophy, sociology, and a range of other disciplines in the study of the profession's past, present and future. He is also co-founder and chair of the International Physiotherapy History Association Executive, and founding Executive member of the Environmental Physiotherapy Association. David's own research work focuses on the critical history of physiotherapy and considers how physiotherapy might need to adapt to the changing economy of health care in the 21st century. He has published numerous peer-reviewed articles and book chapters, many as first author. He was co-editor on the first collection of critical physiotherapy writings - Manipulating Practices - and he is lead editor for the follow-up titled Mobilising Knowledge, which is due out in 2020. He is also very active on social media, writing nearly 700 blogposts for criticalphysio.net over the last 5 years. David has taught in physiotherapy programmes in the UK and New Zealand for over 25 years and has presented his work all around the world. The End of Physiotherapy - the first book-length critical history of physiotherapy, and written by David - was published by Routledge in mid-2017, and a second sole-authored book titled Physiotherapy Otherwise, will be published in 2021. 